\title{
A MÚSICA EM RIBEIRÃO PRETO: DA BANDA SÃO SEBASTIÃO À USP-FILARMÔNICA
}

\author{
Prof. Dr. Rubens Russomanno Ricciardi \\ (Faculdade de Filosofia, Ciências de Ribeirão Preto da Universidade \\ de São Paulo) \\ rubensricciardi@gmail.com
}

A região de Ribeirão Preto possui história recente. Seu povoamento remonta ao terceiro quartel do século XIX, impulsionado em especial pelo café, que, como se sabe, nos primórdios de seu ciclo, contava com mão de obra escrava. $\bigcirc$ processo de urbanização e do estabelecimento econômico da região se deu também pelas mãos de brasileiros que vieram de outras regiões do país, em grande maioria das minas, já então há muito exauridas. Imigrantes que fugiam de crises econômicas em seus países - oriundos da Europa (em especial da Itália), do Oriente Médio e Extremo Oriente - completaram o contingente dos assim chamados "desbravadores". Em meio a esta demanda civilizatória multifária tiveram início também as atividades musicais em Ribeirão Preto no final do século XIX e início do século XX.

Duas instituições devem ser citadas preliminarmente em matéria de música em Ribeirão Preto: a lgreja Matriz de São Sebastião (construída na década de 50 do século XIX e demolida em 1904 - situavase aproximadamente onde se encontra hoje a fonte luminosa da Praça XV) e o Theatro Carlos Comes (inaugurado em 1897 e demolido em 1944, situava-se no terreno da atual Praça Carlos Comes, também no centro da cidade).

Portanto, entre 1897 e 1904, ambas as edificações de enorme importância histórica para a música se situaram a poucos metros de distância uma da outra. 


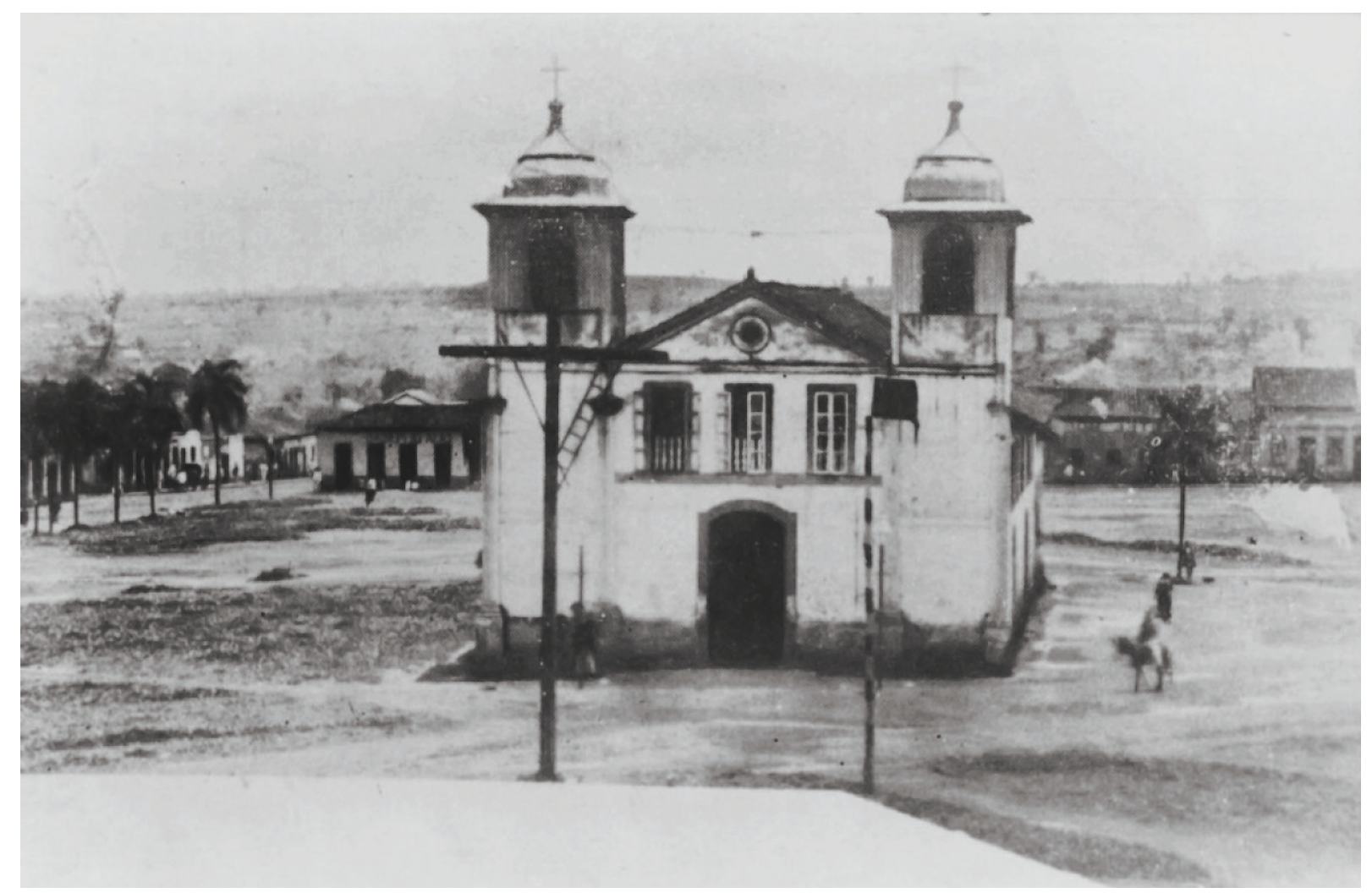

Igreja Matriz de São Sebastião em Ribeirão Preto ( 1868).

Foto do Arquivo Público e Histórico de Ribeirão Preto.

A Banda São Sebastião, a mais antiga corporação musical de Ribeirão Preto que se tem notícia, cuja atuação abrange os últimos anos da monarquia e os primeiros anos da república, esteve atrelada à lgreja Matriz de São Sebastião. Ao lado de outros recém chegados à região, cuja origem hoje se torna de difícil reconhecimento em sua totalidade (mais provavelmente mineiros, e, menos provável, europeus), é possivel que escravos ou alforriados (na época se dizia forros) também tenham atuado entre seus músicos. Como se sabe, entre as atividades humanas, a música é aquela que, pelo menos no Brasil, desde os primórdios da escravidão, mais viabilizou a ascensão social de negros e pardos - e de maneira ainda mais contundente desde os tempos de Marquês de Pombal com sua política colonial de inserção enquanto déspota esclarecido.

Na história do Brasil muitos escravos não só obtiveram a liberdade por conta do talento musical, mas tornaram-se também oficiais em milícias ou galgaram posições eclesiásticas, entre outras honrarias. 
Este último é o caso de Pedro Xavier de Paula (oriundo de Guaratinguetá, com datas ainda desconhecidas de nascimento e morte), a primeira liderança musical de Ribeirão Preto.

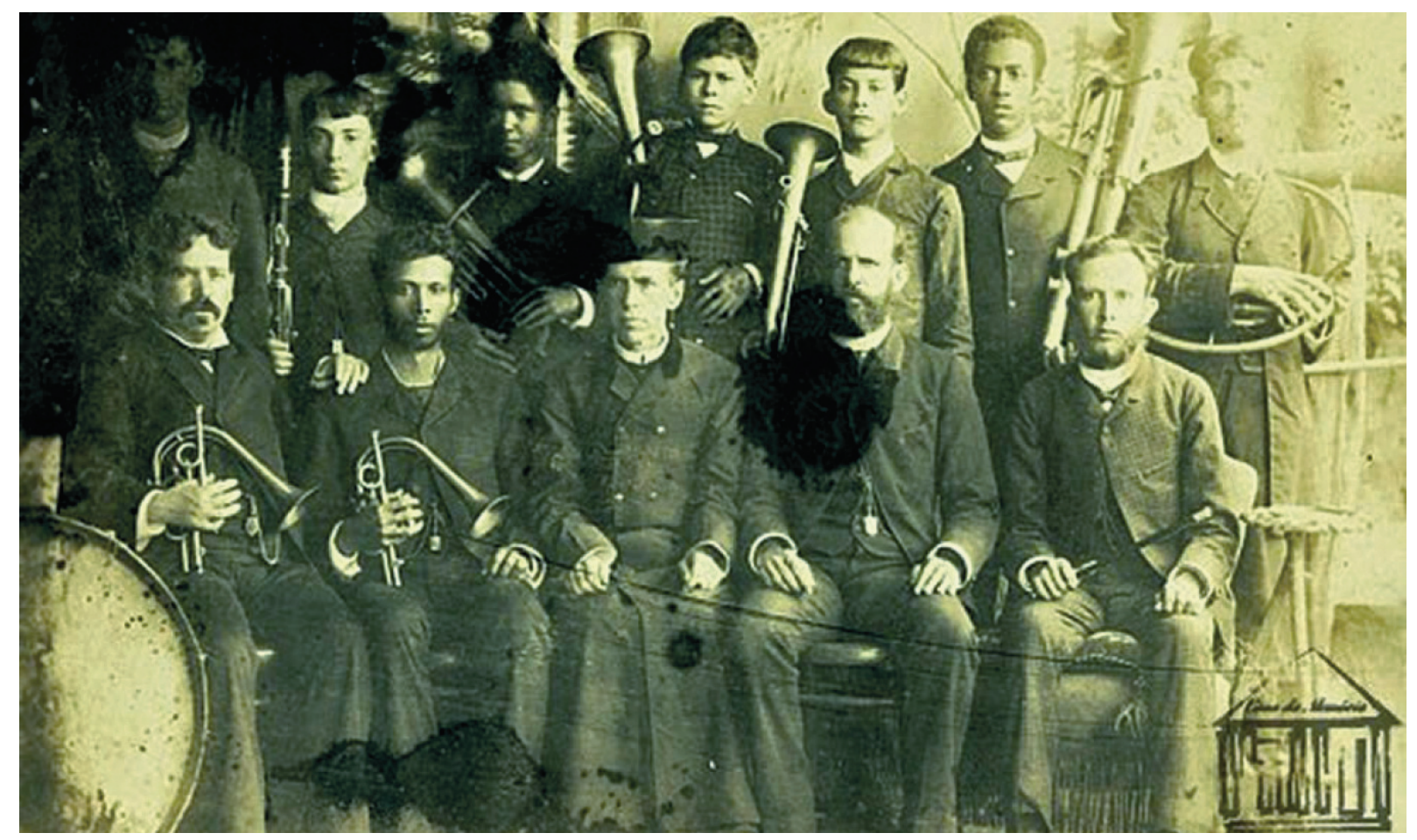

Banda São Sebastião - Foto do Arquivo Público e Histórico de Ribeirão Preto (Registro 284)

A Banda São Sebastião está retratada neste que é o documento iconográfico mais antigo da música em Ribeirão Preto. Esta foto acima remonta ao final da década de 70 do século XIX, com o vigário da paróquia, o italiano Nunzio Grecco (atuou em Ribeirão Preto de 1877 a 1890), ao centro, sentado, e, de pé, o terceiro da esquerda para direita, Pedro Xavier de Paula, aqui um músico ainda bastante jovem. Pedro Xavier de Paula - também citado por cronistas como "alfaiate negro", ou ainda pelo apelido de "Pedro Músico" ou "Pedro Tudo" -, seria posteriormente o mestre desta banda e também, de 1887 a 1889, o importante fabriqueiro da Matriz de São Sebastião. Portanto, ele se tornou não só autoridade musical como também da adminis-

A informação de que Pedro Xavier de Paula foi fabriqueiro da Igreja Matriz de São Sebastião, em Ribeirão Preto, remonta à tese de doutorado Do santo? ou de quem... Ribeirão Preto - gênese da cidade mercadoria (p.208) de Valéria Eugênia Carcia, defendida em 2013, junto ao IAU-USP (Campus de São Carlos). 
tração e das finanças da igreja local.

O repertório da Banda São Sebastião, tal como ocorria em muitas bandas de música daqueles anos em Minas Gerais, Rio de Janeiro e São Paulo, era composto basicamente por música sacra, em grande parte com adaptações de obras do período colonial brasileiro.

A Banda São Sebastião participava das procissões, atuava na Semana Santa, bem como atendia ao exigente calendário católico dos tempos do Padroado. Com a proclamação da república que instaurou o estado laico, contudo, a Banda São Sebastião entrou em decadência, levando-a a uma precoce extinção. Infelizmente, nem seu arquivo musical sobreviveu aos tempos.

A própria Igreja Matriz também foi demolida numa ação articulada pela Câmara Municipal, tendo-se em vista o lema positivista "abaixo as velhas taperas" da velha república, que em nome do progresso e da modernização justificava seu espírito antimonárquico, antilusitano e anticlerical.

Outro fato que pode ter contribuído para a extinção da Banda São Sebastião foi a política da própria lgreja Católica para com a música, notadamente por conta do Motu proprio, intitulado Tra le sollecitudini, publicado em 1903. O papa Pio X proibia então, na música religiosa católica, qualquer repertório distante do cantochão (canto gregoriano medieval) ou da polifonia clássica (renascentista do século $X V I$ ). Este escrito apostólico papal sobre a música na igreja pode ter sido fatal não só para a Banda São Sebastião, como provocou também, não em raros casos, a extinção de antigas corporações musicais religiosas no Brasil, incluindo-se seus arquivos coloniais e do século XIX. Ou seja, perderam-se obras sacras de compositores locais no Brasil porque não atendiam mais às novas diretrizes do papa em Roma. 


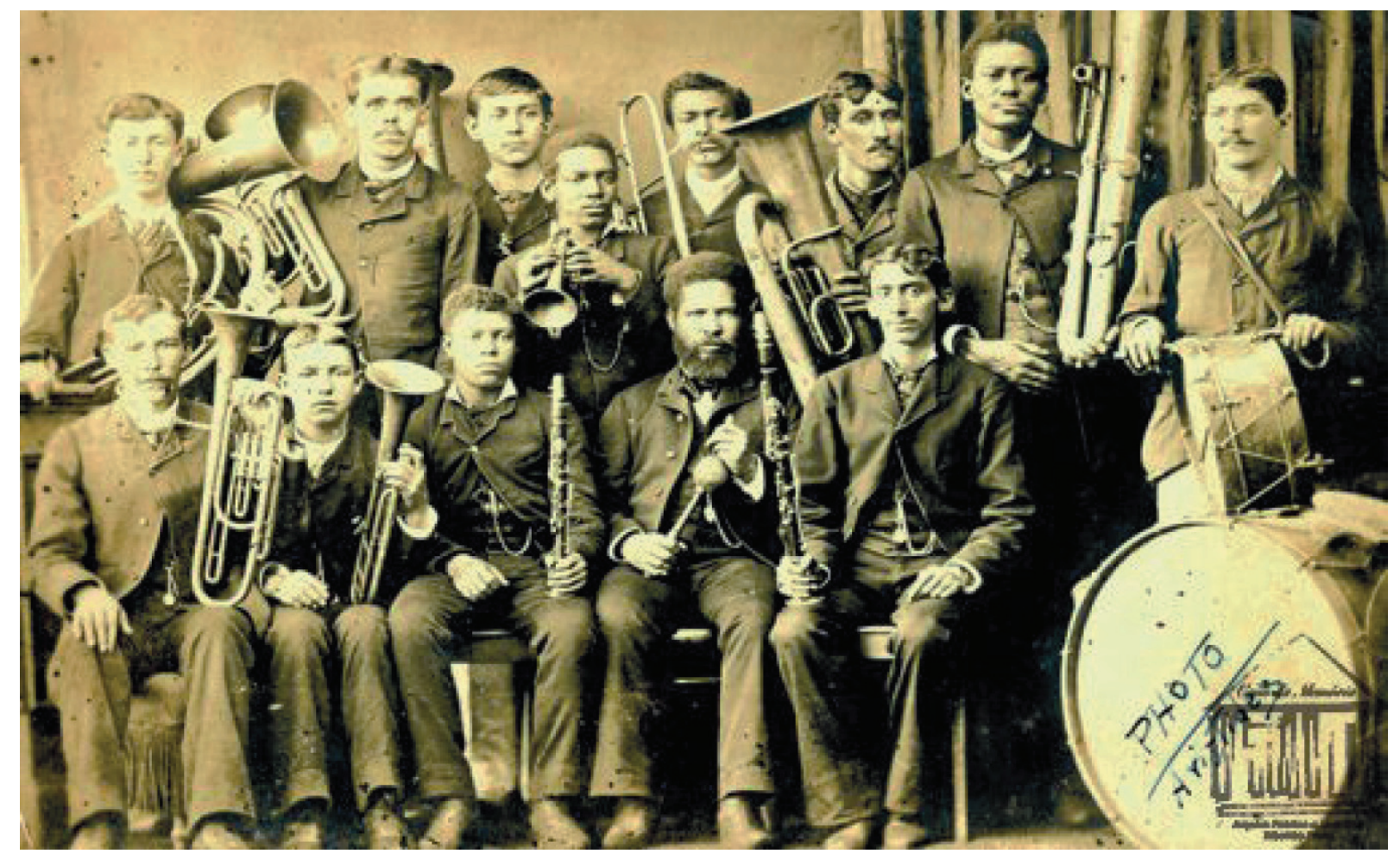

Banda São Sebastião - Foto do Arquivo Público e Histórico de Ribeirão Preto (Registro 283)

De acordo com a informação manuscrita acrescentada sobre a reprodução do bumbo - PHOTO / Aristides - sabe-se que esta segunda foto da Banda São Sebastião foi tirada pelo fotógrafo Aristides Motta na última década do século XIX. $\bigcirc$ mesmo Pedro Xavier de Paula na foto anterior com Sax-Horn Alto reaparece agora sentado, ao centro, já mais velho, com barba, segurando uma baqueta de bumbo. É possível que outros músicos constem também em ambas as fotos, como é o caso certamente do Oficleide - em ambas as fotos de pé, segundo da direita para a esquerda. Com outros instrumentos também podem constar os mesmos músicos, como Helicom / Barítono (Bombardino), Sax-Horn Alto, Clarineta (dúvida músico), Trombone (dúvida músico e instrumento) e Eufônio / provavelmente outro instrumento grave.

Passando agora da música religiosa para a profana, o monumental Theatro Carlos Gomes é exemplo significativo não só de uma vocação artística presente na cidade desde sempre, como também registra seu espírito historicamente empreendedor e ousado em projetos musicais. 


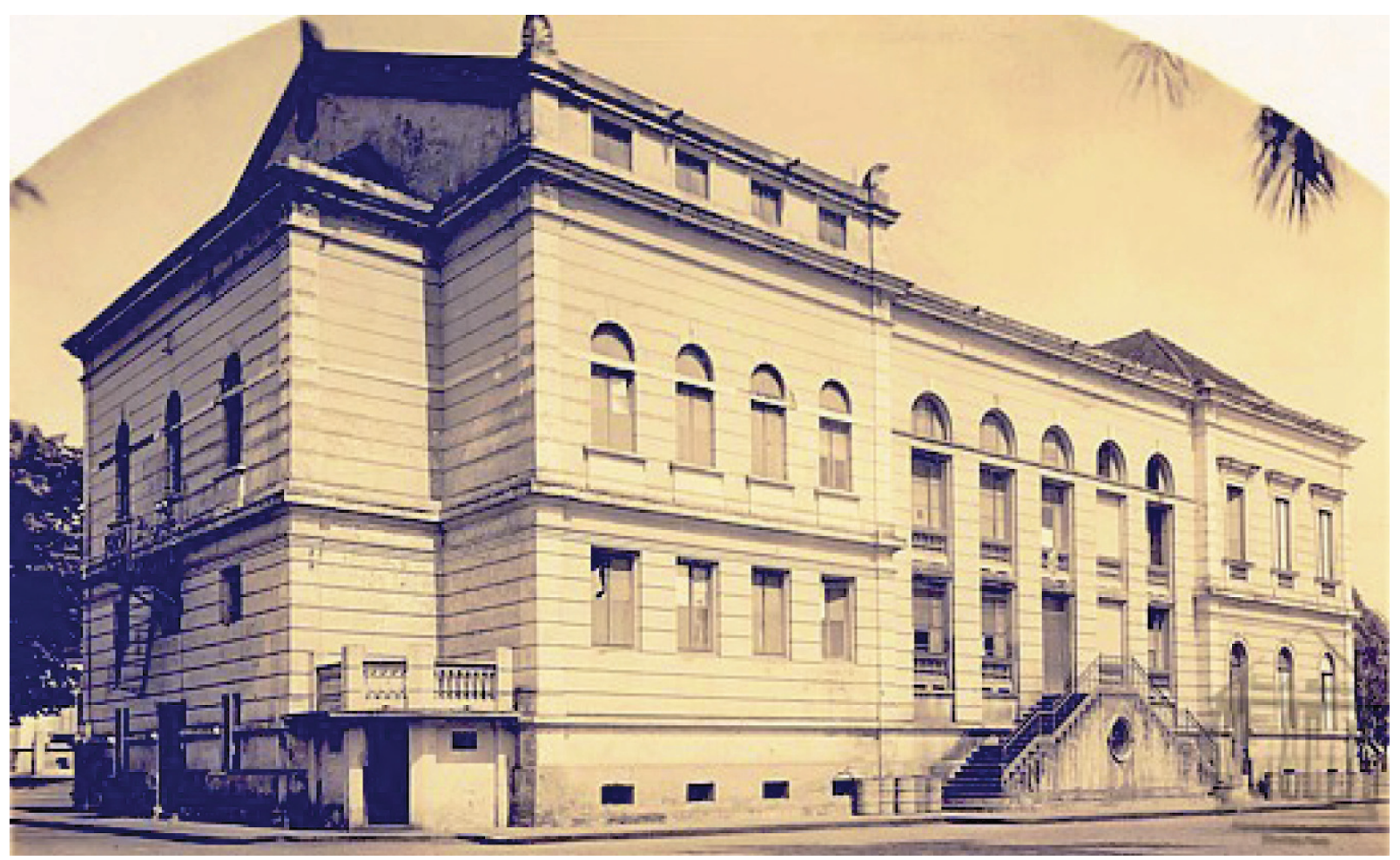

Theatro Carlos Comes - Foto do Arquivo Público e Histórico de Ribeirão Preto (Registro 307)

Com a decadência do repertório sacro, a música em Ribeirão Preto passa a ter outros focos de atuação. Em 1905, temos notícia da Banda de Conegundes Rangel (?-1964) se apresentando com seus novos repertórios numa festa na Capela de Santo Antônio (hoje ainda existente, na Avenida da Saudade, próxima à Rua Rio de Janeiro):

Festa de Santo Antonio - Com toda a pompa realisouse hontem na Capella de Santo Antonio nesta cidade, a festa do grande e popular Santo Antonio de Lisbôa. Foi celebrante da missa o Revdmo. Sr. Padre Euclides Comes Carneiro. Tocou em todos os actos religiosos a banda musical do Sr. Conegundes Rangel. A concurrencia dos fieis áquelle templo foi enorme (Jornal "A Cidade", 14 de junho de 1905).

maestro Conegundes Rangel foi funcionário público estadual (na Secretaria da Fazenda) e professor, fundador a primeira escola pública de Viradouro, em 1915, tendo atuado também em Casa Branca. Rangel é um exemplo de músico compositor amador atuante 
em Ribeirão Preto no início do século XX. Fontes primárias de várias de suas obras se encontram hoje depositadas no Centro de Memória das Artes da FFCLRP-USP. Entre outros, há títulos como Rio Branco - Gran Dobrado; Valsa; Ciúmes d'arte - Sinfonia; Sem malícia - Tango; Ingênua - Schotisch; Ore di Meditazione - Mazurka; Paródia - Sinfonia e A cidade - Marcha.

Já a Filhos de Euterpe, uma banda de música ainda mais importante, foi regida pelo maestro José Delfino Machado (18?? - São Paulo, 1942) - que residiu em Ribeirão Preto por muitos anos. Em 1901 , há notícia de apresentação sua na inauguração do novo jardim "do Dr. Loyola" (Praça XV), com Hino Nacional e Marselhesa. Já em 1909, a Filhos de Euterpe foi premiada em segundo lugar num concurso de bandas em São Paulo. Na foto abaixo temos o maestro e compositor Delfino Machado (único de perfil, bem à esquerda) à frente de sua banda Filhos de Euterpe:

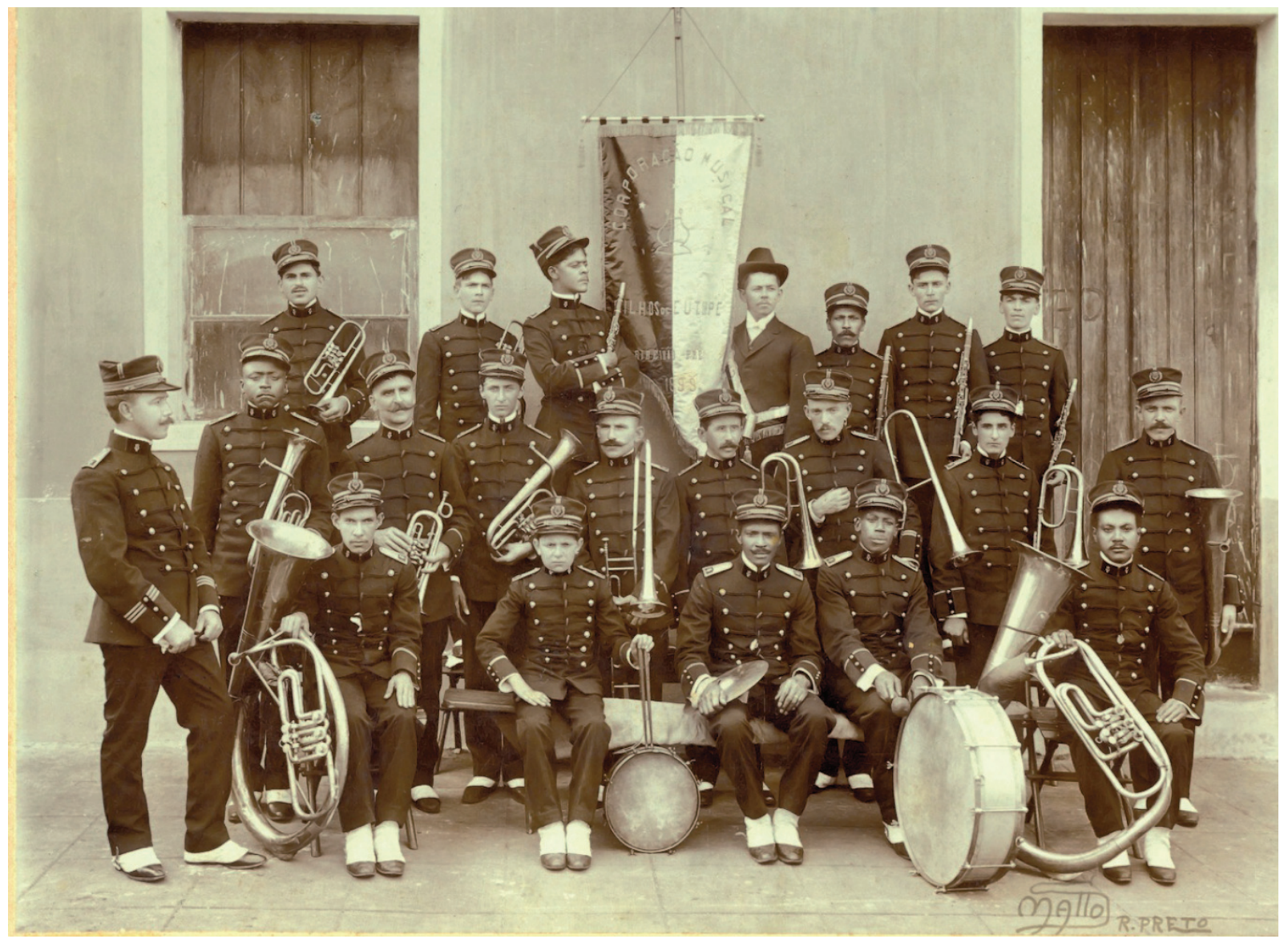

Banda Filhos de Euterpe - Foto do Arquivo Público e Histórico de Ribeirão Preto (Registro 153) 
José Delfino Machado foi também compositor produtivo. Fontes primárias de várias de suas obras se encontram hoje depositadas no Centro de Memória das Artes da FFCLRP-USP.

Entre outros, há títulos como Vagaroza - Polka; Mellancolica (Melancholica) - Valsa; Amor filial - Mazurka; Recreação - Fantasia; Sempre gelozza - Valsa lenta; Deuzina (Deusinha) - Mazurka; Valsa brasileira sensivel; Capital d'oeste - Passo doppio symphonico; Capadocio - Rapisodia; Minas Ceraes - Marcha; Chateau dos promptos - Habanera; O teu regimento - Marcha; O cordão - Tango; Odeon (19/4) Marcha - para a inauguração do novo Cine Odeon; Triumphal - Passo doppio; Marcha final; O Bandoleiro - Tango; Zezinha - Mazurka; Morrer de amores - Phantasia grande; Um samba no Bom Retiro; Na floresta Mazurka; Invencivel - Marcha; Los pimpolhos e Marcha; Canção arabe - Melodia.

Delfino Machado seria ainda o primeiro maestro da Orquestra Sinfônica de Ribeirão Preto (doravante OSRP), nos anos de 1920. Na foto a seguir podemos observar, além do maestro Delfino Machado (quinto da esquerda para direita, sentado à frente), outros músicos importantes, como Max Bartsch (na fileira do meio, terceiro da esquerda para a direita, que seria o fundador da Sociedade Musical em 1938 , além de um importante articulador musical junto à PRA-7, Rádio Clube de Ribeirão Preto, compositor e tocava cítara, importante funcionário da Cervejaria Paulista), o spalla Hermenegildo Beretta (na fileira de trás, o segundo da esquerda para a direita) e o pianista e maestro Carlos Nardelli (sentado à frente, quarto da esquerda para a direita).

Lembramos ainda que a foto da página seguinte é a mais antiga da OSRP: 


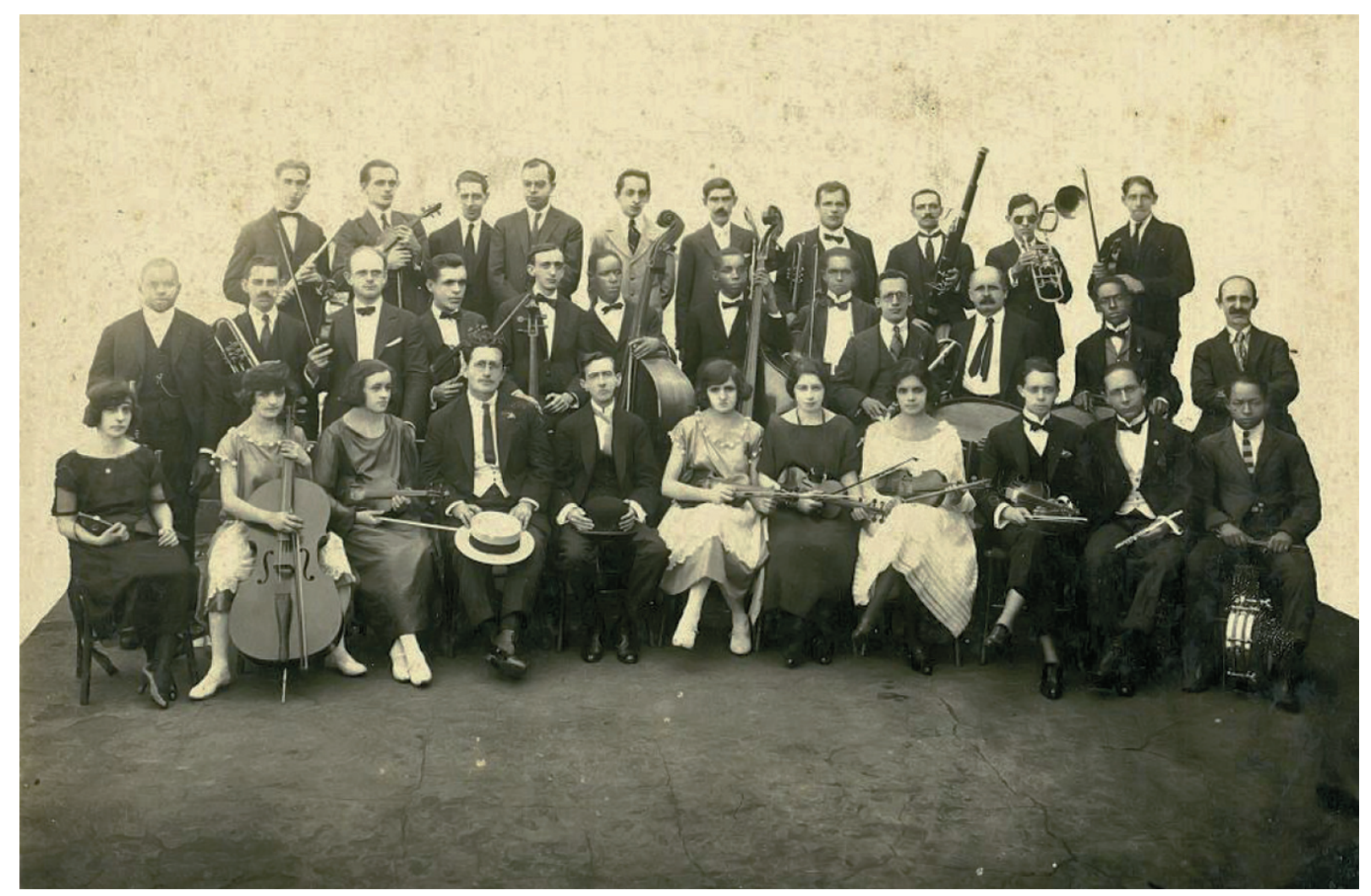

OSRP ( 1923) - Foto do Centro de Memória das Artes da FFCLRP-USP

(Coleção Belmácio Pousa Codinho)

Belmácio Pousa Godinho (Piracicaba, 1892 - Ribeirão Preto, 1980), atuante em Ribeirão Preto desde 1917, é um nome também importante da música na cidade. Seu acervo pessoal (contendo notícias de jornais, fotos, documentos pessoais e a maior parte de suas partituras impressas e manuscritas) encontra-se depositado no Centro de Memória das Artes da FFCLRP-USP. Além de músico, foi jogador de futebol do XV de Piracicaba e do Comercial Futebol Clube (tendo sido também seu presidente), e, por muitos anos, proprietário da Loja "A Musical" de pianos e partituras, que se localizava na Rua Ceneral Osório, fundada em 1919. Também flautista da OSRP (como se observa de sua foto acima, na fileira do meio, o quarto da direita para a esquerda), Belmácio Pousa Godinho é compositor do Hino do Comercial Futebol Clube e Supremo Adeus, entre outras obras que marcaram época.

A estreia do Hino do Comercial Futebol Clube se deus logo após a excursão vitoriosa da esquadra alvinegra ribeirãopretana pelo nordeste do Brasil, noticiada pela imprensa local. Nota-se que o Hino 
do Comercial abria e encerrava a retreta, ao lado de árias de óperas e operetas do século XIX, entre outros, de Lehár e Verdi:

Jardim Publico - A Banda "Independente", em homenagem aos valorosos e bravos rapazes do "Commercial F. C." executará hoje no coreto do Jardim Público, o seguinte programma:

\section{Parte}

- Hymno do Commercial F. C., B. Pousa Codinho

- Aida, final do segundo ato, C. Verdi

- Viúva alegre, fantasia, Franz Lehar

- Sonho dourado, dueto, V. Ceorgio

II Parte

- Trovador, Aria, C. Verdi

- Brasillianita, Ouvertur, N.N

- Colloqui d'Amore, Duetto, N.N

- Hymno do Commercial F. C., B. Pousa Codinho

(Jornal "A Cidade", 6 de junho de 1920)

A OSRP, das mais antigas do Brasil e, desde 1938, mantida pela Associação Musical, tornou-se uma entidade de importância histórica para a música em Ribeirão Preto. Fundada por músicos amadores, vem tentando um difícil processo de profissionalização desde os anos 90 do século passado, uma vez que se trata da única orquestra sinfônica profissional no Brasil não mantida com recursos públicos.

Um dos maestros, músicos e diretores da OSRP, Edmundo Russomanno (Bragança Paulista, 1893 - Ribeirão Preto, 1963), também foi compositor. Seu acervo de autógrafos musicais se encontra hoje depositado também no Centro de Memória das Artes da FFCLRP-USP. Entre outros, há títulos de composições suas como Primavera - fantasia para clarineta e orquestra; Canto dos Bandeirantes; Carlos Roberto tango; O Orphão - Dobrado; Samba do crioulo - para banda; Ave Maria para coro e orquestra e Sublimação - Valsa para piano, além de inúmeras obras para piano, missas e chorinhos. 


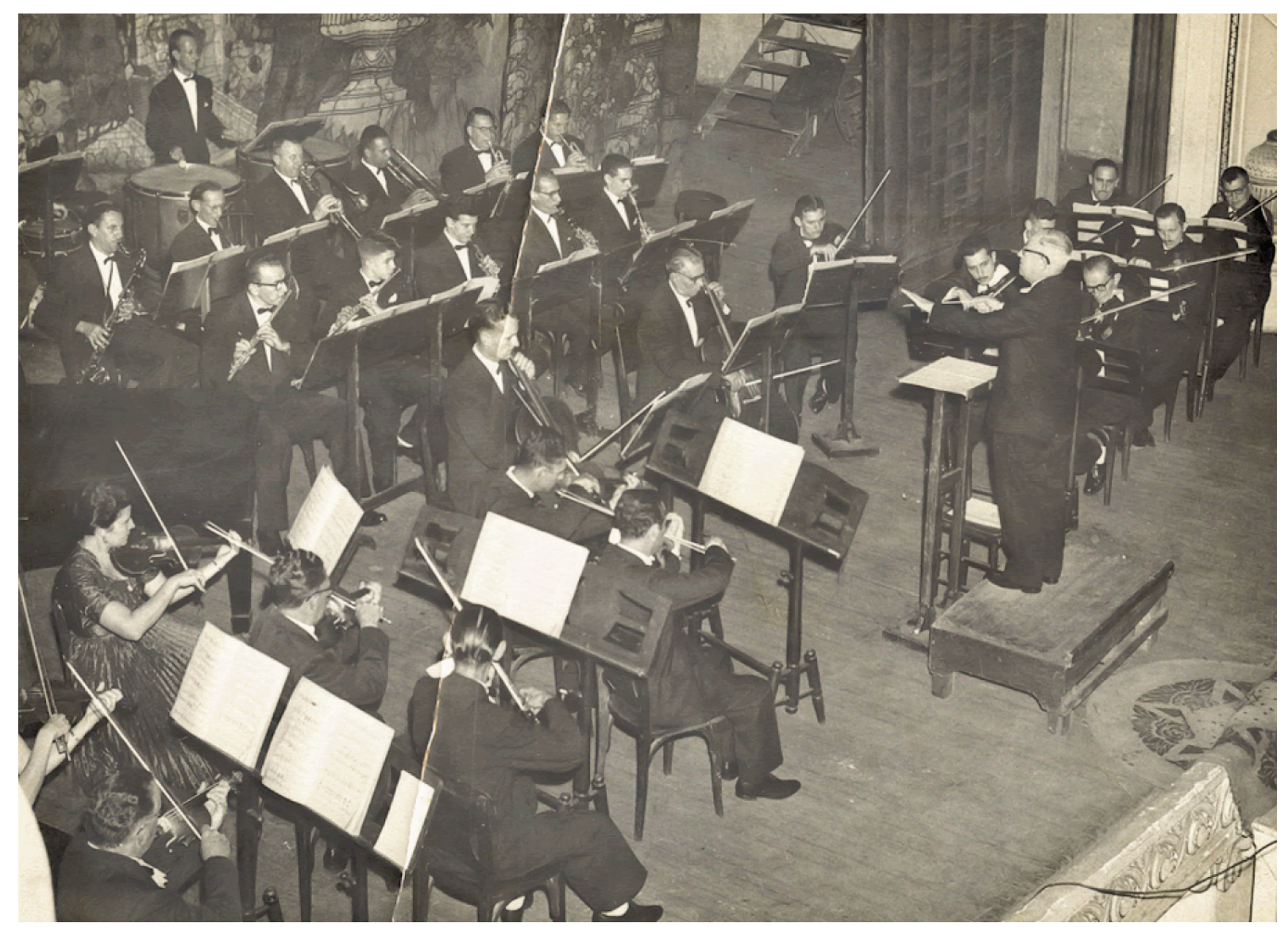

OSRP ( 1951 ) regida por Edmundo Russomanno - Foto do Centro de Memória das Artes da FFCLRP-USP (Coleção Edmundo Russomanno)

Esta última foto já marca a atuação da OSRP no monumental Theatro Pedro II, inaugurado em 1930. Trata-se de um dos melhores palcos para a música no Brasil. Com capacidade para mais de 1500 ouvintes, é um teatro de ópera com excelente fosso de orquestra e acústica perfeita tanto para música cantada com cena como para concertos sinfônicos e mesmo música de câmara.

Em sua primeira fase, dos anos 20 do século passado até 1962, a OSRP atuou enquanto orquestra clássica a 2 e a 3 em cada naipe de sopros (flautas, oboés, clarinetas, fagotes, trompas, trompetes e trombones), tímpano e cordas (com oito primeiros violinos / oito segundos violinos/três violas/dois violoncelos/dois contrabaixos). Contava com bons e variados regentes, tais como José Delfino Machado, Carlos Nardelli, Cônego Barros, Antônio Giammarusti, Edmundo Russomanno, Dinorá de Carvalho, Armando Belardi e Enrico Ziffer, tendo sido Ignácio 
Stábile o principal regente por maior tempo. Em seus repertórios houve estréias de obras de compositores residentes na cidade, como Pietro Ciammarusti, Belmácio Pousa Godinho, Edmundo Russomanno e Ignácio Stabile, entre outros. De seus projetos realizados no Theatro Pedro II constavam também récitas de óperas completas, como II Guarany, Rigoletto, La Traviata e Madame Butterfly. Outros destaques se deram na programação constante de compositores brasileiros, nomes como Antônio Carlos Comes, Henrique Oswald, Luiz Levy, Alexandre Levy, Alberto Nepomuceno, Francisco Braga e Francisco Mignone, entre outros.

A PRA-7 Radio Clube de Ribeirão Preto transmitia ao vivo por telefone os concertos da OSRP diretamente do Theatro Pedro II.

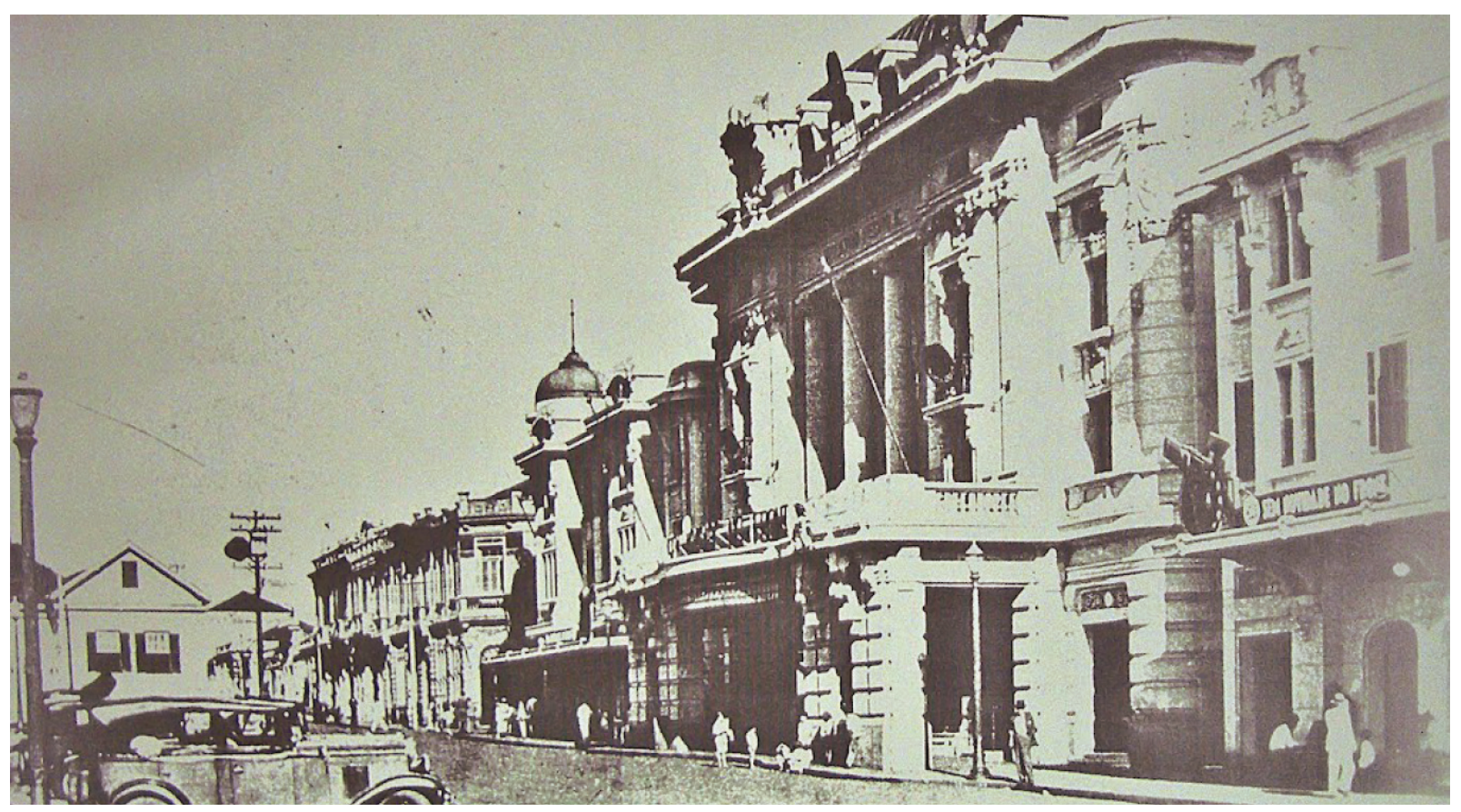

Theatro Pedro Il logo após sua inauguração (ca. 1930)

Podemos citar um exemplo do espírito inovador dos repertórios apresentados pela OSRP, como no concerto de 21 de setembro de 1956, sob regência do maestro convidado Jorge Kaszás (maestro húngaro, 1915-2002), com obras de Mozart (Serenata no 6 e a Abertura da ópera $\bigcirc$ Rapto do Serralho), Bartók (Dos quadros da Hungria), Katchaturian (Gayameh), Leopoldo Miguez (Elegia), Alexandre Levy (Samba), Cláudio Santoro (Ponteio) e Guerra-Peixe (A Inúbia do Caboclinho 
e Ponteado), com vários músicos extras convidados de São Paulo.

Em sua segunda fase, de 1962 a 1994, a OSRP foi inicialmente regida por Spartaco Rossi (regente titular), havendo posteriormente um aumento acentuado das dificuldades, com problemas técnico-operacionais, perspectivas artísticas redutivas, quase não havendo regentes convidados, bem como com uma triste estagnação de seus repertórios. Somava-se a tudo isso ainda a decadência do Theatro Pedro II (que após adaptações para se transformar em cinema sofreu um terrivel incêndio em 1980).

Já em sua última fase, desde 1995, a OSRP passa por um amplo e sempre difícil processo de profissionalização, mas com acentuada evolução técnica e artística dos quadros e bons regentes titulares (Roberto Minczuk, depois Cláudio Cruz).

Com número expressivo de bons regentes e solistas convidados (Alex Klein, Günter Neuhold, Antônio Meneses, Ricardo Castro, Fernando Portari, Rosana Lamosa, Felix Krieger, Fabio Martino, entre outros), houve uma renovação dos repertórios já numa orquestra clássica completa. Destacam-se projetos como o "Juventude tem Concerto", os "Concertos Internacionais", "Concertos OHL" (com a gravação de CDs), bem como se incluindo ainda a realização de montagens completas de récitas de óperas, como Die Zauberflöte (em parceria com a Cia Minaz), Cavalleria Rusticana, Rigoletto e La Boheme.

Toda esta agenda vem sendo articulada também com maior sucesso desde a reinauguração do Theatro Pedro II, em agosto 1996, que voltou a ser teatro de ópera com suas excelentes configurações originais - não obstante a boa reforma que modernizou suas instalações gerais. 


\section{Curso de Música no Campus da USP em Ribeirão Preto}

A questão que se colocava, portanto, na década de 90 do século passado era esta: numa cidade e região com tão forte tradição de atividades musicais e operísticas, com uma excelente e rara casa de ópera como o Theatro Pedro II, não seria oportuna a criação e o estabelecimento de uma escola de música pública e gratuita e que pudesse desenvolver o ensino da música com a mais alta qualidade técnica e artística? A ideia de se fundar no campus ribeirãopretano da Universidade de São Paulo um curso superior de música remonta ao início da década de 1990, iniciativa esta que se deve a alguns docentes da FMRP-USP, apreciadores da arte e da ciência da música, pois já haviam fundado o Grupo Pró-Música de Ribeirão Preto, que, desde 1969, promove séries de música de câmara na cidade.

Deve-se registrar o empenho pessoal e institucional de vários professores da USP, com especial destaque a Moacyr Antônio Mestriner (então prefeito da PCARP) e Wilson Roberto Navega Lodi, ambos da FMRP-USP, que atuaram ao nosso lado e nos deram todo o apoio para o sucesso do projeto. Eu atuava então inicialmente como aluno de pós-graduação e depois já como professor do Departamento de Música da Escola de Comunicações e Artes da USP em São Paulo, no final dos anos 90 do século passado. Tivemos a grata oportunidade de redigir o projeto em comissão designada pela Reitoria da USP.

Conselho Universitário da USP, presidido pelo magnífico reitor Jacques Marcovich, deliberou a criação e a instalação do Curso de Música no Campus de Ribeirão Preto como extensão da ECA de São Paulo a 31 de julho de 2001. A 26 de setembro daquele ano, nós éramos nomeados para a primeira coordenação da ECA-USP em Ribeirão Preto. Áquela época, destaca-se ainda, para a consolidação do projeto, a importante atuação dos professores Lor Cury (então secretária geral da USP), Ada Pellegrini Grinover (pró-reitora de Graduação da USP) e Waldenyr Caldas (diretor da ECA). A primeira 
turma em Música pela ECA-USP em Ribeirão Preto foi selecionada pelo Vestibular 2002. A aula inaugural ocorreu a 5 de março de 2002, na Sala de Concertos da Tulha, com a Aula Magna de Waldenyr Caldas - também com a presença do prefeito municipal Antônio Palocci Filho e demais autoridades universitárias e regionais - evento este finalizado com concerto da OSRP, sob regência de Cláudio Cruz.

A Sala de Concertos da Tulha (prédio do último quartel do século XIX, outrora tulha de café da Fazenda Monte Alegre de Francisco Schmidt) já havia sido reinaugurada em 1997. Desde então, a Sala de Concertos da Tulha - que passou a pertencer ao Curso de Música - tornou-se um dos mais importantes locais para apresentações de corais e música de câmara na região de Ribeirão Preto.

Para que o curso pudesse almejar um status de excelência nacional e internacional, a primeira tarefa que se tornava urgente - enquanto linha prioritária para as futuras pesquisas - era sua consolidação enquanto curso regional. Assim, em 2004, foi criado o Bacharelado em Instrumento Viola Caipira, projeto pioneiro no gênero, consolidando as essenciais interfaces da arte da música com a cultura caipira local.

Outra iniciativa essencial foi a reunião e depósito na USP de arquivos e documentos históricos da música em Ribeirão Preto e região. Numa ação conjunta nossa com José Gustavo Julião de Camargo, hoje maestro e funcionário de nível superior da FFCLRP-USP, intermediamos a aquisição de coleções de partituras, manuscritos e documentos iconográficos das bandas locais já extintas, bem como de compositores e músicos tais como Belmácio Pousa Codinho, Edmundo Russomanno, Gaetano Baccega e, recentemente, Gilberto Mendes. Tais fontes se tornaram, desde 2012, o Centro de Memória das Artes da FFCLRP-USP, ainda em processo de instalação e consolidação, com apoio da Pró -Reitoria de Cultura e Extensão Universitária da USP. 


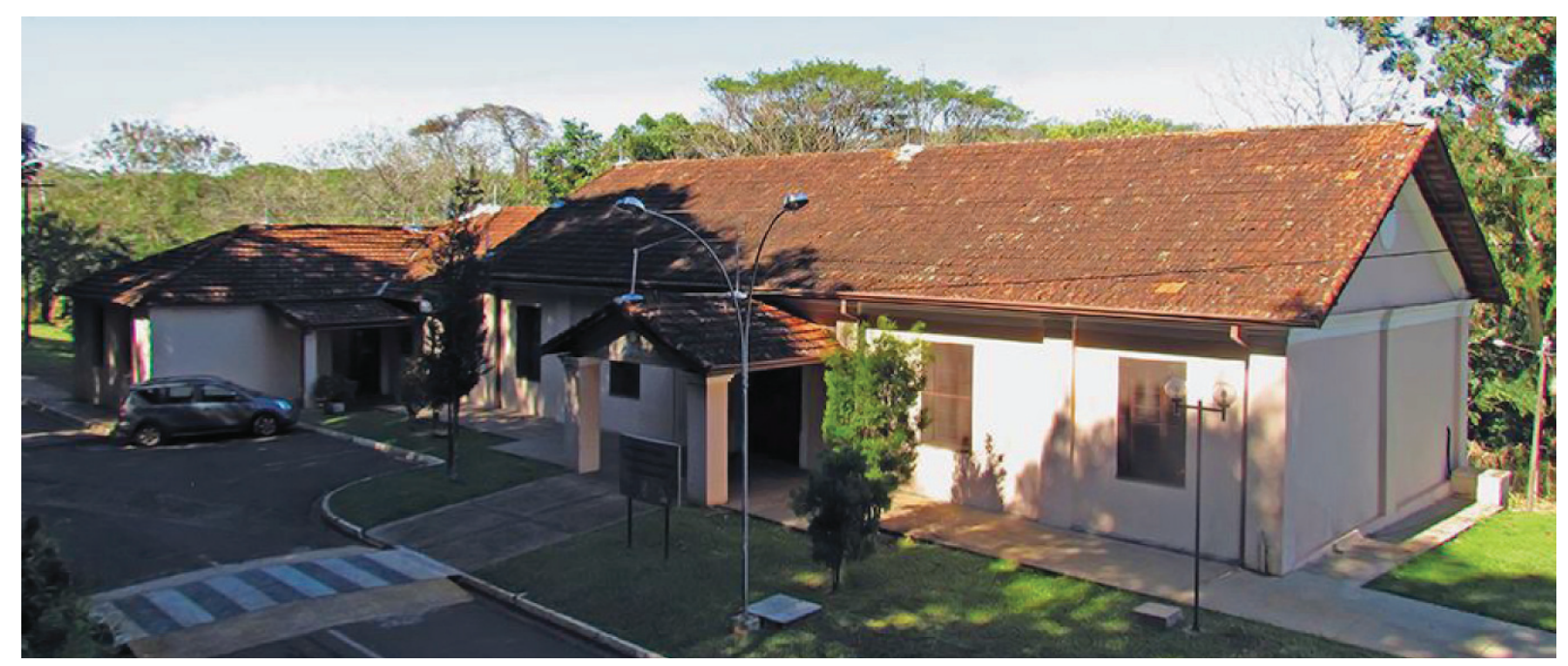

Sala de Concertos da Tulha e também sede do NAP-CIPEM da FFCLRP-USP e do Centro de Memória das Artes da FFCLRP-USP

Graças à atuação da coordenadora do Curso de Música ao longo de 2010, Silvia Maria Pires Cabrera Berg, sob liderança do diretor da FFCLRP-USP, Sebastião de Sousa Almeida, e de sua vice-diretora, Catarina Satie Takahashi, o Conselho Universitário da USP, presidido pelo magnífico reitor, João Grandino Rodas, deliberou a criação do Departamento de Música da FFCLRP-USP a 14 de dezembro de 2010. Encerravam-se assim definitivamente as atividades da ECA no Campus de Ribeirão Preto. E o Curso de Música (bem como demais projetos de ensino, pesquisa e extensão, incluindo-se o início desde já de um projeto de uma nova pós-graduação) torna-se responsabilidade do novo Departamento de Música da FFCLRP-USP, com conselho departamental próprio e constituído por massa crítica local e comprometida diretamente com o bom desenvolvimento da música no Campus de Ribeirão Preto da USP.

De 2002 a 2010 , a massa crítica de professores foi crescendo, chegando a um total de 15 claros docentes. Atualmente, em novembro de 2014, o DM-FFCLRP-USP conta com os seguintes professores: Rubens Russomano Ricciardi (titular), Rodolfo Coelho de Souza e Diósnio Machado Neto (associados), Silvia Maria Pires Cabrera Berg, Fernando Corvisier, Fátima Corvisier, Yuka de Almeida Prado, Régis Rossi Faria, Simone Corete Machado, Marcos Câmara de Castro, Gustavo Silveira 
Costa e Eliana Guglielmetti Sulpício (doutores). Está sendo realizado, em 20 I4, concurso para contratação de professor de violoncelo, bem como há negociação para a reposição de dois claros docentes juntos à ECA-USP que pertencem ao Departamento de Música da FFCRLP-USP. O gargalo do curso no momento é a falta de professores de instrumentos, havendo necessidade urgente destas contratações para o fortalecimento do Bacharelado em Instrumento, bem como a contratação de professores de apoio às atividades de canto, para o fortalecimento do Bacharelado em Canto e Arte Lírica.

Um projeto importante em andamento é a criação de um Mestrado Profissional em Performance Musical, cujo inicio está previsto para um futuro próximo.

O Departamento de Música da FFCLRP-USP promove ainda Encontros de Musicologia (em 2014 ocorreu sua sexta edição, sob curadoria científica de Marcos Câmara de Castro) e festivais de música - como o Festival Música Nova "Gilberto Mendes", numa parceria com o SESC-SP, tendo o Campus da USP de Ribeirão Preto como sede principal desde 2012 (em 2014 ocorreu a $48^{\circ}$ edição, sob nossa curadoria artística), e as séries mensais de concertos, como a Temporada de Música de Câmara (uma das mais antigas e tradicionais do Brasil, desde 1969, sempre na última terça-feira de cada mês, em parceria com o Grupo Pró-Música e a Fundação D. Pedro II) e os Concertos USP, em parceria com a FDRP-USP (Auditório da FDRP-USP) e o IFSC-USP (com concertos no Auditório Sérgio Mascarenhas do IFSC-USP e no Teatro Municipal de São Carlos).

O atual chefe do DM-FFCLRP-USP é Gustavo Silveira Costa e, seu vice-chefe, Fernando Crespo Corvisier. Na coordenação do curso (Bacharelado em Canto e Arte Lírica, Bacharelado em Instrumento e Licenciatura) se encontra Fátima Monteiro Corvisier².

Além do prédio da Tulha, as diversas ampliações do DM-FF-

2 Este texto foi escrito em 2014. 
CLRP-USP viabilizaram uma excelente estrutura física para suas atividades acadêmicas, com a Casa 11 (Rua dos Bambus), Casa 15 (Rua das Paineiras) e o amplo e moderno prédio didático, o Bloco 34 da FFCLRP-USP. Além da estrutura física de excelência, o DM-FFCLRP-USP adquiriu recentemente uma grande quantidade de instrumentos musicais das melhores marcas musicais, entre eles sete pianos Steinway (além de um oitavo piano Steinway também adquirido pela FDRP-USP e utilizado pelo Departamento de Música em seus concertos no Auditório da FDRP-USP), dois conjuntos completos de instrumentos de percussão, bem como harpa e vários instrumentos de sopro.

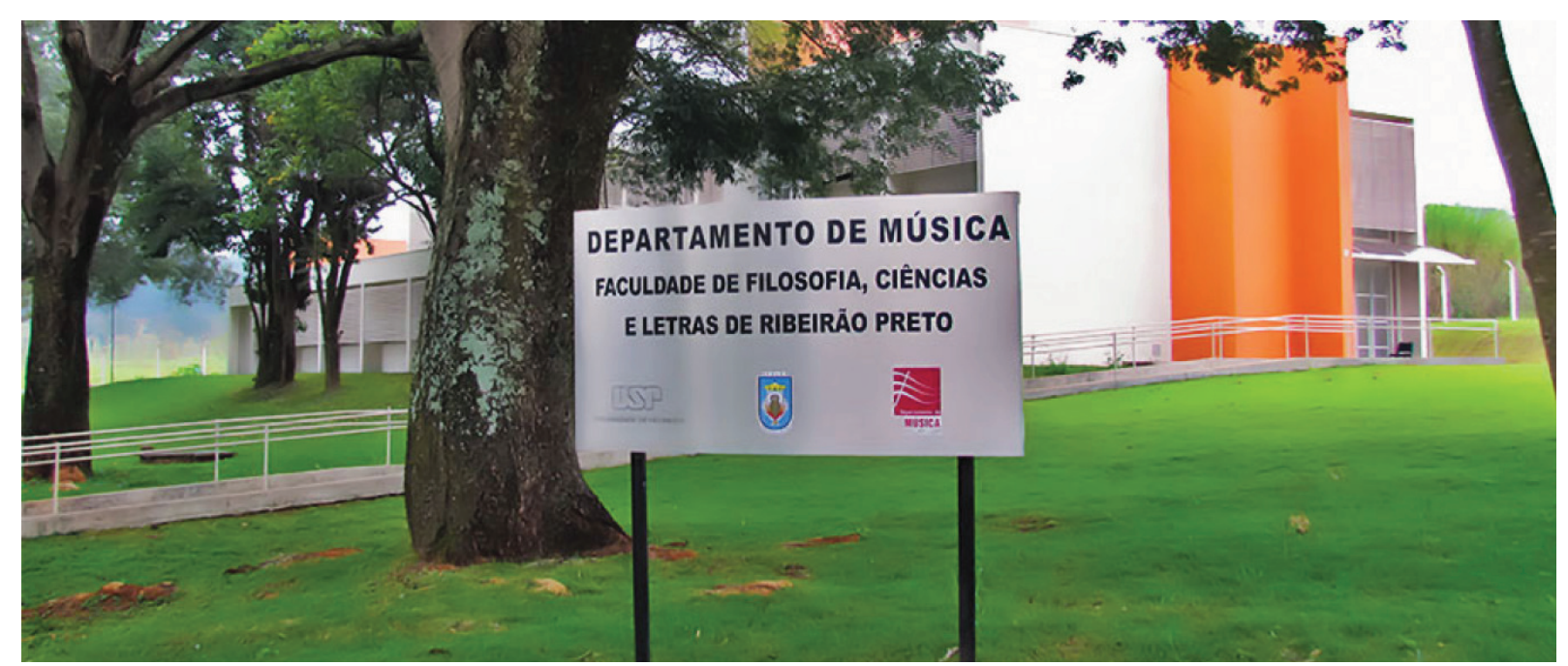

Bloco 34 da FFCLRP-USP (20 | 4) - Bloco didático do Curso de Música

Departamento de Música da FFCLRP-USP conta atualmente com dez funcionários locados em três blocos distintos: Prédio da Tulha - Rua Mário de Andrade: Luiz Aparecido dos Santos (Analista para Assuntos Administrativos), André de Sousa Estevão (Auxiliar de Administração) e José Gustavo Julião de Camargo (Orientador de Estruturação Musical). Na Casa 15 - Rua das Paineiras: Célia Cardoso Meirelles (Secretária de Departamento), Eliana das Neves Araújo (Secretária -Técnico 3), Waldyr José Comes Fervença (Secretário), Cristiano Henrique Ferrari Prado (Técnico de Laboratório) e Lucinéia Martins Levandosqui (Auxiliar de Serviços Cerais). E no Bloco Didático 34 - Rua Maria M.C. Teles: Sonia Regina de Oliveira (Técnico para Assuntos Administrativos) e Tiago Francisco Silva de Araújo (Auxiliar de Serviços Gerais). 
Não obstante o enorme progresso dos últimos anos em equipamentos, instrumentos musicais e espaços físicos, o Departamento de Música teve ainda seu projeto aprovado em seu mérito pela Congregação da FFCLRP-USP para a construção de uma casa de ópera, intitulada USP-Ópera, no Campus da USP de Ribeirão Preto, que seria essencial não só para a consolidação dos bacharelados em instrumento e canto, como também para a produção de óperas contemporâneas produzidas pelo próprio departamento, num fecundo processo acadêmico de inovação.

Em funcionamento desde 2002, e, desde 2011 , pertencendo à FFCLRP-USP, o Curso de Música da USP de Ribeirão Preto já produz frutos e tem contribuído favoravelmente para o desenvolvimento da educação musical em Ribeirão Preto e região. Destaca-se a participação essencial de ex-alunos que estão atuando atualmente em diversos projetos, como o Projeto Curi do Estado de São Paulo e projetos de escolas de música Savegnago em Sertãozinho e ALMA no Palace (espaço cultural da Prefeitura Municipal de Ribeirão Preto), entre outras realizações.

Segundo a coordenadora do curso, Fátima Monteiro Coriviser, cada habilitação do curso de música comporta disciplinas específicas relacionadas às competências e habilidades da Licenciatura em Música, do Bacharelado em Instrumento e do Bacharelado em Canto e Arte Lírica. São disciplinas da área de música que têm o objetivo de empreender uma sólida capacitação profissional. Algumas disciplinas obrigatórias para uma habilitação são optativas para outra, o que propicia ao aluno do Curso de Música na FFCLRP-USP uma formação diferenciada e abrangente, seguindo as Diretrizes do Conselho Nacional de Educação para os Cursos de Graduação em Música, Dança Teatro e Design (CNE/CES O 195/2003). Os alunos do Curso de Música, em suas três habilitações, contam ainda com atividades de pesquisa, ensino e extensão ligadas aos laboratórios do Departamento de Música, a saber: Laboratório de Musicologia - LAMUS; Laboratório de 
Ciências da Performance - LCP; Laboratório de Acústica e Tecnologia Musical - LATM; Laboratório de Teoria e Análise Musical - LATEAM; Laboratório de Piano e Pedagogia do Piano- PIANOLAB; Laboratório de Percussão e Percepção Rítmica - LAPPER; Laboratório de Piano em Grupo - LPG.

\section{Filosofia de trabalho do DM-FFCLRP-USP}

Em relação à filosofia geral de atuação do DM-FFCLRP-USP, deixando de lado o caráter excludente do par teoria/prática, trabalhamos com o princípio de que são pelo menos três (e não dois) os fundamentos das atividades musicais. Relacionamos assim os três principais ofícios da música: 1) composição (ofício do compositor), 2) interpretação/execução (ofício do instrumentista, cantor e regente) e 3) musicologia (ofício do pesquisador em música).

\section{Composição - poíesis em música}

Podemos conferir equivalências à poíesis com nossos verbos produzir, fazer, fabricar, inventar, compor. A poética (ou poiética, pois se trata do ensino da poíesis), neste sentido primordial, compreende ao mesmo tempo a concepção (projeto, programa, manifesto normativo) e a produção (composição, realização da escritura) da obra de arte. O conceito é válido não só para a poesia, mas também para todas as artes, incluindo-se a música. Tudo que envolve o trabalho de um compositor é sua poética musical. Dos três ofícios da música a composição é a atividade mais artística em sua essência. Segundo Adorno, a composição, "em todos os tempos, sempre decide sobre a posição da música". E se Friedrich Hölderlin dizia que "o que permanece, inauguram os poetas", o mesmo procede com os compositores. Cada grande compositor também inaugura a história. Portanto, a música enquanto arte é também história em seu sentido mais essencial. Segundo Heidegger, "a arte funda a história". A composição musical é tanto fundamento da 
história quanto invenção. Luigi Pareyson enaltece o caráter inventivo da arte, já que "o simples fazer não basta para definir sua essência. A arte é também invenção. Ela não é execução de qualquer coisa já idealizada, realização de um projeto, produção segundo regras dadas ou predispostas. Ela é um tal fazer que, enquanto faz, inventa o por fazer e o modo de fazer". Justifica-se assim que lgor Stravinsky tenha se definido certa vez não como compositor, mas como "inventor de música".

O compositor atua com três condições essenciais em seu ofício. A primeira condição no ofício de compositor diz respeito ao caráter operativo do artesão, condição esta importante para o ofício como um todo. $\bigcirc$ compositor precisa lidar com as ferramentas de trabalho e demais recursos artesanais com plena desenvoltura. Se nem todo artesão é um artista, todo artista deve ser necessariamente um artesão. Como afirma Pareyson, "o oficio [de artesão] tem uma curiosa prerrogativa: pode existir sem a arte, enquanto, pelo contrário, a arte não pode passar sem ele". Já segundo Paul Ricoeur, "o autor [artista] é o artesão em obra de linguagem". E se a primeira condição tem a ver com disciplina, já a segunda, num evidente conflito insolúvel, diz respeito a um exercicio de liberdade. Esta segunda condição no ofício de compositor, relacionada à sua fantasia inventiva (enquanto capacidade de imaginação), é também o alcance de uma singularidade solitaria em sua poíesis. Podemos afirmar que a música só se dá na singularidade solitária da obra. A terceira condição no ofício de compositor é a exposição de mundo. Trata-se das questões além-música, as chamadas referências externas que configuram a autonomia relativa do material musical - mesmo que as questões do métier interno da música sejam por si só apaixonantes e inesgotáveis. Falamos aqui que a obra musical culmina na exposição de mundo enquanto interação existencial, o compositor numa postura crítica entre ideologias e utopias. Heidegger define neste mesmo sentido o Dasein - um dos conceitos centrais em sua filosofia. A obra musical não se configura apenas no métier e na capacidade inventiva do compositor, mas é acima de tudo linguagem enquanto morada do ser. 


\section{Interpretação/execução - práxis em música}

A práxis diz respeito à prática, ação, aplicação, execução, sempre já implicando uma condição de destreza. No caso do intérprete-executante em música, a prática vem sempre já precedida do estudo das fontes musicais, de um exame rigoroso e detalhado da partitura. Além da escritura musical do compositor, que deve ser exaustivamente estudada, há ainda o mundo da obra exposta, bem como o contexto histórico-estilístico deste mundo, sua paisagem pictórica, sua poesia. É por isso que para o músico executante o constante exercício de interpretação e ainda mais, uma atividade mesmo hermenêutica, é uma conditio sine qua non em seu ofício. E daí também sua dupla condição, tanto interpretativa como performática. Em latim há a expressão que bem define este ofício: mente manuque. Em 1993, fundamos o Ensemble Mentemanuque, voltado à música contemporânea, tendo como princípio esta atividade de interpretação/execução musical nas mais estreitas relações com a pesquisa musicológica e com a composição musical preferencialmente inédita. Ou seja, ao mesmo tempo uma habilidade mental (hermenêutica) e uma manual (e mais que com as mãos, executando música com o corpo num todo, tocando um instrumento, cantando ou regendo). Devemos lembrar que a poética (produtivo, inventivo) é diferente da prática (ação). Segundo Aristóteles, "há que se distinguir o que é produtível daquilo que é realizável pela ação. A produção (poiesis) é diferente da ação (práxis). Assim, a disposição prática conformada por um princípio racional é diferente da disposição produtora conformada por um princípio racional. Assim, nenhuma das duas é envolvida pela outra, porque nem a ação é produção nem a produção é ação". É por isso que dizemos corretamente que um intérprete performático não tem um estilo, mas sim ele interpreta e executa o estilo de cada compositor. Eis as diferenças entre composição e interpretação/execução em música. Mas não raramente se fala por aí de um suposto "estilo de intérprete" ou "estilo de interpretação". Como o intérprete performático - aquele que trabalha na área das práticas interpretativas - poderá possuir um estilo próprio? Há que se estar atento 
às incontornáveis idiossincrasias de um intérprete-performático. Por um lado, o compositor não pode perder de vista as especificidades bem como toda possibilidade de recurso para o meio musical para o qual escreve. Afinal, na escritura musical de hoje já está mais que sugerido todo um conjunto de informações voltado à execução. Por outro lado, o intérprete-performático tem uma inequívoca obrigação de fidelidade à poética do compositor. Mas existe ainda sim e sempre um amplo espaço por parte do intérprete-performático para exercer seu ofício com dignidade. No entanto, se pensarmos na escritura musical do século XVIII para trás como exemplo de indicações restritas quase que exclusivamente às alturas e às durações, como poderemos então insistir na tese de tal fidelidade ao compositor por parte do intérprete/executor, ainda mais com toda esta recente discussão da performance com instrumentos de época? Este já é outro problema, pois os processos notacionais mais antigos realmente não nos dão referências definitivas ou integrais para a resolução de questões interpretativo-performáticas. Mas devemos lembrar que a escritura musical no século XXI viabiliza já um conjunto mais aperfeiçoado tanto quanto detalhado de sinais notacionais para os diversos parâmetros musicais.

\section{Pesquisa musicológica - theoria em música}

Teoria é em sua origem um neologismo. Embora não se possa precisar qual autor o utilizou primeiramente, a data de aparecimento deste conceito coincide com o surgimento da filosofia nos séculos VII e VI a.C (mais provável VI do que VII, ou na virada de um século para outro). Até então havia dois verbos relativos à visão, oráo e blépo, indicando o fenômeno do olhar imediato. Enfim, equivalente aos nossos verbos olhar e ver. Contudo, com o aparecimento de theoréo temos o início de um modo de visão que, ainda que dependa da visão sensivel, atravessa essa sensibilidade no intuito de penetrar agudamente no que seria a natureza (phýsis) dos fenômenos. Daí que originalmente a palavra theoria significa uma praxis da visão, uma visão analítica do concreto, aquela que pretende ver a fundo as coisas ao redor, 
um modo distinto do olhar. É por isso que se torna precária - sob um ponto de vista tanto histórico quanto filosófico - qualquer suposição hoje de uma teoria apartada do mundo real. Ela não seria nem certa nem errada. Apenas não faria sentido enquanto teoria. Neste sentido também, a teoria de modo algum é oposta à prática, mas sim, encontra-se em oposição à abstração. Se é teoria, não pode ser jamais uma abstração ex nihilo. Abstração é um atributo da poíesis, não da theoria. E por theoria em música, tendo-se em vista as origens históricofilosóficas do conceito, podemos entender hoje a musicologia como um todo. A pesquisa em música deve abranger necessariamente história, crítica, estética e poética, análise estrutural, sistemas harmônicos, teoria da interpretação/execução e edição musical, em suas evidentes relações com as demais questões internas e externas à música, bem como com suas interfaces com outras áreas do conhecimento. A musicologia trata também dos universos musicais, suas diferenças $e$ interfaces. Neste amplo sentido, a pesquisa musicológica é uma atividade de estudo, essencialmente hermenêutica, contemplando toda possibilidade analítica, observacional, especulativa e editorial em música. $\bigcirc$ musicólogo se encontra ainda em meio às contradições do conflito insolúvel entre cultura e arte, analisando os processos de aculturação - num incontornável processo permanente de fusão cultural - bem como das manifestações musicais em meio às mais amplas perspectivas interdisciplinares.

\section{Fusão de horizontes}

Finalizadas as análises sobre as três grandes áreas da música na filosofia de trabalho do DM-FFCLRP-USP, concluímos que se deve evitar a especialização precoce por parte do estudante de música. Deve-se estimular antes o constante exercício de cruzamento e fusão de horizontes entre estas três principais áreas da música. Não vivemos num horizonte fechado, nem tampouco num único horizonte, daí a necessidade de uma compreensão transcendental, quando procuramos compreender a perspectiva do outro. Para ser mais claro, o aluno de composição deve por bem conhecer os amplos problemas da interpre- 
tação/execução e da pesquisa em música. $\bigcirc$ aluno das práticas interpretativas deve se inteirar profundamente sobre as questões relativas à composição e à musicologia. E o futuro musicólogo não poderá jamais exercer seu ofício com a devida dignidade se não conhecer em detathes $e$ intensamente tanto a atividade do músico intérprete-performático como aquela do compositor. Antes destas etapas não poderemos sequer falar sobre uma formação específica de um professor de música. E, ainda mais importante, as referências externas à música não podem ser ignoradas, pois não há artista e/ou pesquisador de fato que não saiba pensar ou desprovido de um espírito crítico.

\section{NAP-CIPEM e os corpos estáveis do Departamento de Música da FFCLRP-USP}

Os grupos musicais do DM-FFCLRP-USP enquanto atividades integradas de ensino, pesquisa e extensão são: Grupo de Percussão de Ribeirao Preto - GRUPURI (sob direção de Eliana Sulpício); Coral de Alunos (sob direção de Marcos Câmara de Castro), Oficina Experimental da Voz e Oficina Experimental de Instrumentos (sob direção de Silvia Maria Pires Cabrera Berg), Mogiana Jazz-Band (sob direção de José Gustavo Julião de Camargo), In Tempori Duo (com Carlos Sulpício, trompete, e Eliana Sulpício, percussão) e Duo Corvisier (duo pianístico com Fástima Corvisier e Fernando Corvisier). Além de laboratórios e grupos de pesquisa, o DM-FFCLRP-USP conta com o Núcleo de Pesquisa em Ciências da Performance em Música (NAP-CIPEM). $\bigcirc$ principal projeto hoje do NAP-CIPEM é a série de Livros-CDs, intitulada "Coleção USP de Música", integrando a pesquisa musicológica publicada na forma de livros acrescentada de gravações artísticas (produzidas pelo próprio estúdio do NAP-CIPEM). Não só os professores desenvolvem projetos individuais como atuam em conjunto, como é o caso dos projetos de gravação envolvendo o Ensemble Mentemanuque.

Fundado em 1993, numa ação conjunta com Diósnio Machado Neto e Domingos lunes Elias, e, desde então, sob nossa direção 
artística, o Ensemble Mentemanuque é um grupo de música de câmara voltado principalmente à divulgação da música brasileira contemporânea e a recuperações histórico-musicológicas (numa relação indissociável entre composição, interpretação/execução e pesquisa musical). Constituído inicialmente por solistas da OSRP, desde 2002, o Ensemble Mentemanuque também conta com os solistas (docentes, alunos e funcionários) do Curso de Música de Ribeirão Preto da ECA-USP (Escola de Comunicações e Artes da USP). Finalmente, desde 2011, o Ensemble Mentemanuque passa a ser integrado por solistas do Departamento de Música da FFCLRP-USP e em especial da USP-Filarmônica. Desde 2012, suas atividades estão estreitamente relacionadas com o Núcleo de Pesquisa em Ciências da Performance em Música (NAP-CIPEM). O Ensemble Mentemanuque desenvolve trabalhos conjuntos com regentes e solistas convidados. Apresentou-se em Ribeirão Preto (Casa do Advogado, SESC, Teatro Municipal, Theatro Pedro II, Centro Cultural Capela da USP e Auditório da Faculdade de Direito de Ribeirão Preto da USP), São Paulo (Centro Cultural São Paulo, Teatro Sérgio Cardoso, MASP e Teatro Anchieta do SESC-Consolação), Prados (Lira Ceciliana), Tiradentes (Matriz de Santo Antônio), Santos (Teatro Municipal e Teatro Guarany) e São Carlos (Auditório Sérgio Mascarenhas do IFSC-USP).

$\bigcirc$ Ensemble Mentemanuque contou com as participações de regentes convidados, como Aylton Escobar, Aldo Brizzi (Itália) e Philip Hefti (Suíça), bem como de solistas convidados, como Mathias Allin (Flauta, Alemanha), Andrea Kaiser (Soprano), Denise de Freitas e Adriana Clis (Mezzo-Soprano). No exterior, já se apresentou na Sala de Concertos da Academia de Música da Basiléia (Suiça), no Teatro Municipal de Münster (Alemanha), no Teatro Savoia pela série de concertos da Associação de Amigos da Música em Campobasso (Itália), no Museu Internacional de Cerâmica de Faenza (Itália) e no Teatro Municipal de Cento (Itália) - sempre com repertório de música brasileira. Gravações de concertos pela Radio Cultura-FM de SP e pela Radio $\mathrm{BBC}$ de Londres. Participações no XIX Festival de Música de Prados; XXIX, XXX, XXXI, LVIV, XLVI, XLVII e XLVIII Festival Música Nova "Cilberto Mendes"; na I Bienal de Música de Ribeirão Preto (2004), no Colóquio 
Submodernidades (2010) - Questões da Música Contemporânea (USP/ SESC - RP) e no Festival de Música Contemporânea KlangZeit (2012) de Münster (Alemanha). O Ensemble Mentemanuque apresentou em estréia mundial obras de Cilberto Mendes, Domênico Coiro, Rubens R. Ricciardi, Mário Ficarelli, José Gustavo Julião de Camargo, Silvia Berg, Paulo de Tarso Salles, Marcos Câmara de Castro e Lucas Galon. Em estréias brasileiras, obras Hanns Eisler, Arnold Schönberg, Klaus Ager, Patric Standford, Aldo Brizzi, Giacinto Scelci, Silvia Berg, Piero Niro e Stephen Hartke. Atualmente, o Ensemble Mentemanuque tem tido presença constante de músicos como Yuka de Almeida Prado (soprano), Eliana Sulpício (percussão), Rubens R. Ricciardi (piano), José Custavo Julião de Camargo (viola caipira) e Custavo Costa (violão e viola Caipira), entre outros.

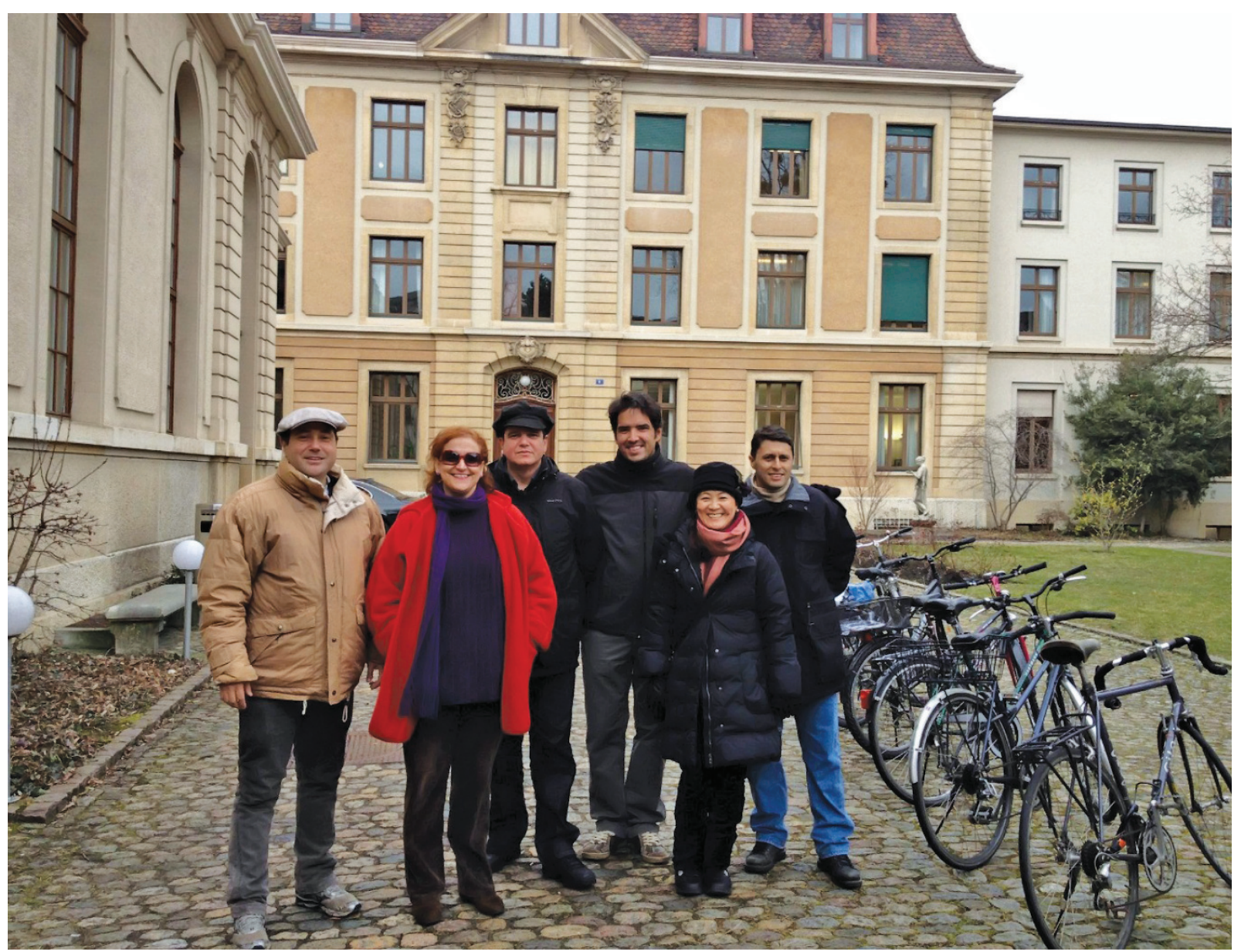

Ensemble Mentemanuque do DM-FFCLRP-USP na Academia de Música da Basiléia (Suiça, 2012) - da esquerda para a direita: Rubens Russomanno Ricciardi, Eliana Sulpício, José Gustavo Julião de Camargo, Gustavo Silveira Costa, Yuka de Almeida Prado e Waldyr José Gomes Fervença 
Destaca-se, por fim, a USP-Filarmônica, a orquestra do Departamento de Música da FFCRLP-USP, fundada em fevereiro de 2011 . Desde 2014 , a USP-Filarmônica conta também com seu próprio Coral, formado por alunos e voluntários da comunidade. Ao nosso lado (atuamos aqui como professor responsável e regente titular), José Gustavo Julião de Camargo (funcionário e regente assistente) atua na direção artística desde a sua fundação.

A USP-Filarmônica conta com trinta bolsas da Reitoria da USP ( 15 bolsas concedidas pela Pró-Reitoria de Cultura e Extensão Universitária e mais 15 pela Pró-Reitoria de Graduação da USP). Concertos sinfônicos e récitas de óperas já foram realizadas em Ribeirão Preto (Theatro Pedro II, Espaço Cultural Capela da USP, Auditório da FDRP -USP, Sala de Concertos da Tulha da FFCLRP-USP e Teatro Municipal), Santos (Teatro do SESC), Barrinha (Teatro Municipal, em sua inauguração), São Carlos (Auditório Sérgio Mascarenhas do IFSC-USP), Jaboticabal (Teatro Municipal), Franca (Teatro Municipal) e Ourinhos (Teatro Municipal). A USP-Filarmônica já apresentou em estréia mundial, obras de Piero Niro, Lucas Galon, José Gustavo Julião de Camargo, Gilberto Mendes, Rubens Russomanno Ricciardi, Marcos Câmara de Castro, Rafael Alexandre Fortaleza e Fernando Emboaba. Participações no XLVI, XLVII e XLVIII Festival Música Nova "Cillberto Mendes" (em sua última edição, destacando-se a participação de Cláudio Cruz como maestro especialmente convidado). A USP-Filarmônica já contou com solistas convidados, incluindo-se alunos e ex-alunos, tais como Yuka de Almeida Prado, Rosana Lamosa, Karen Stephanie, Tatiana Castanheira, Tamara Pereira e Tamara Caetano (sopranos), Denise de Freitas, Carla Odorizzi e Priscila Cubero (mezzo sopranos), Cildo Legure (contratenor), Fernando Portari, Jean William e David Araujo (tenores), Carlos Conzaga Basto e Alezandre Mazzer (barítono), Riane Benedini (flauta), Igor Picchi Toledo (clarineta), Natanael Tomás (trompete), André Luis Micheletti (violoncelo), Gustavo Costa (violão e viola caipira), Juliana D’Agostini e Rodrigo Antônio Silva (piano), entre outros. A filosofia de trabalho da USP-Filarmônica - em consonância com a filosofia peda- 
gógica do DM-FFCLRP-USP, contempla a perfeita e integral unidade da poíesis (a composição ou invenção musical, ofício de compositor) com a práxis (a interpretação-performance, ofício de instrumentista e cantor) com a theoria (a pesquisa em música, ofício do musicólogo), articuladas com os fundamentos de ensino, pesquisa e extensão da universidade pública. Ao lado do repertório contemporâneo do século XXI, a USP-Filarmônica também trabalha com clássicos da música universal, num contraponto entre tradição e inovação, apresentando ainda alternadamente compositores de outros países e brasileiros.

Em relação específica à produção musical brasileira de concerto - um dos focos de trabalho da USP-Filarmônica - seus repertórios abrangem desde o período colonial até o contemporâneo, com forte interface com a produção do NAP-CIPEM do Departamento de Música da FFCLRP-USP enquanto resultado de suas pesquisas histórico-musicológicas. Há também uma dedicação especial às obras inéditas dos próprios compositores locais.

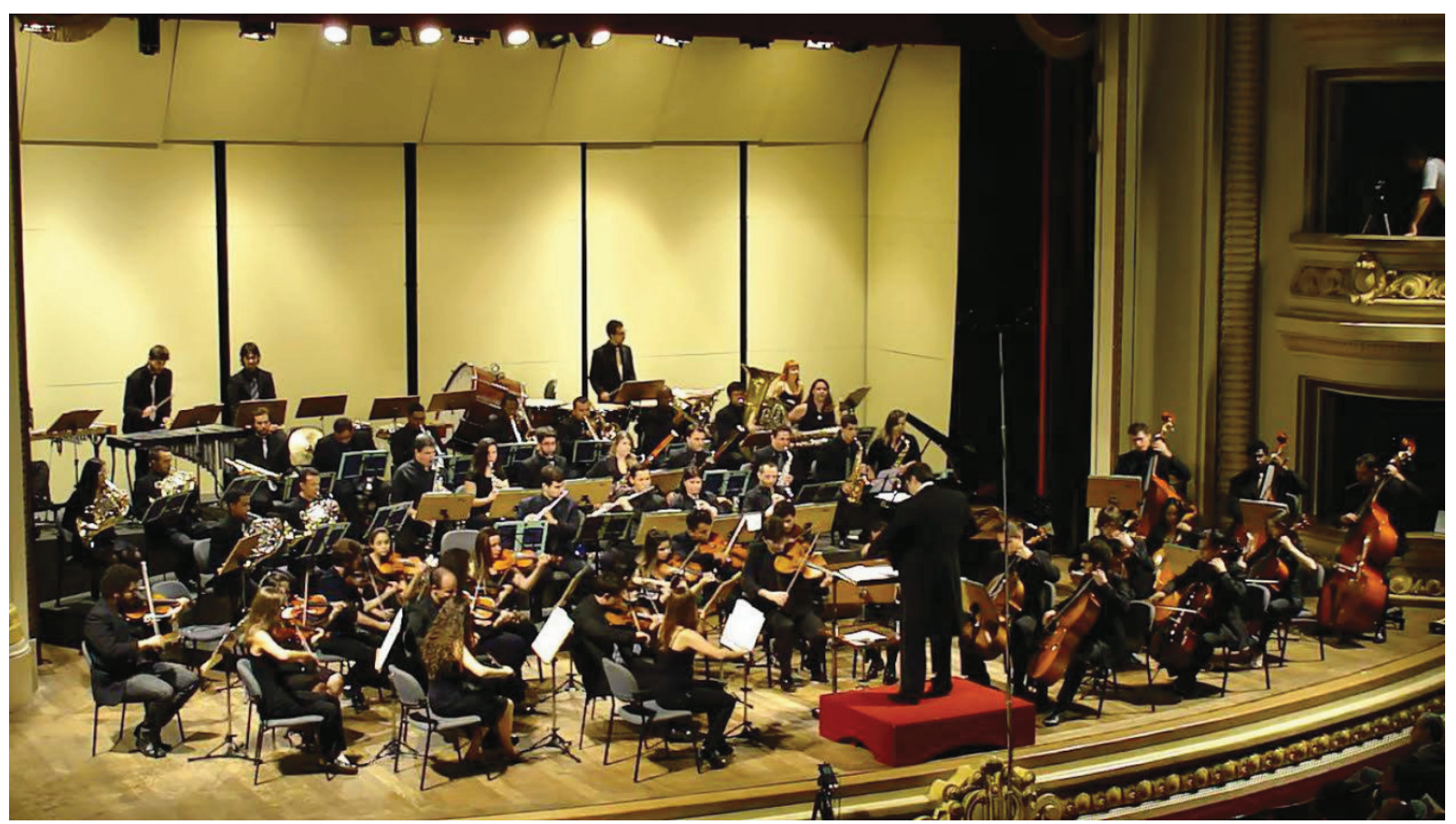

USP-Filarmônica no Theatro Pedro II (20|4),

em concerto comemorativo aos 90 anos da FORP-USP e da FCFRP 